\title{
Analysis of the Influence of Brand Experience and Customer Satisfaction on Brand Loyalty and Its Implications for Willingness to Pay a Price Premium (Study on Herbalife Product Nutrition Customer in East Lombok, West Nusa Tenggara, Indonesia)
}

\author{
Hartiani $^{1}$; Dwi Putra Buana $S^{2}$; Akhmad Saufi ${ }^{2}$ \\ ${ }^{1}$ Master of Management FEB University of Mataram, Lombok, Indonesia \\ ${ }^{2}$ Management Departement FEB University of Mataram, Lombok, Indonesia \\ Email: hartiani78@gmail.com
}

http://dx.doi.org/10.18415/ijmmu.v8i11.3039

\begin{abstract}
This research aims to find out how Brand Loyalty is affected by Brand Experience, how Brand Loyalty is affected by Customer Satisfaction, how Brand Loyalty is affected by Brand Experience through Customer Satisfaction, how Brand Loyalty affects willingness to pay a premium price. The type of research used is quantitative research with causal methods. The population in this study is Herbalife product consumers in East Lombok, with an unknown population. The number of samples taken as many as 100 people, determination of samples with purposive sampling techniques, and data analysis using PLS analysis with SmartPLS application version 3.0. The results showed that all hypotheses proposed in this study were acceptable and positively and significantly influenced. Customer Satisfaction variables can be a good mediation of brand experience and brand loyalty.
\end{abstract}

Keywords: Brand Experience; Customer Satisfaction; Brand Loyalty; Willingness to Pay a Price Premium

\section{Introduction}

Increasing public awareness of the importance of maintaining health during the Covid-19 Pandemic is done by consuming fruits, vegetables, herbal drinks, and nutrients (Lidia et al., 2020). In addition to Covid-19, another worrying factor is the increasing number of obesity that can trigger various degenerative diseases. Based on the results of Basic Health (Riskesdas) research in 2018, there was an increase in obesity by $21.8 \%$, which in the previous study in 2013 was still at $14.8 \%$ (Masrul, 2018). The number of people with obesity may increase in the pandemic with the physical distancing policy. More community activities are carried out at home to increase food consumption and sedentary behaviors that can trigger obesity (Noviasty \& Susanti, 2020).

The increasing public awareness about maintaining health and the growing number of obesity is a great potential for marketing nutrition, especially nutrition weight management (diet). However, it is still 
constrained by the perception of the high price of products (Priambodo \& Najib 2014). There are various brands of weight management nutrition that have premium prices, one of which is Herbalife. Herbalife is a dietary supplement produced by the Global Company founded in 1980 in Los Angeles. Herbalife Nutrition has a variety of products, including F1 Shake Mix, an icon product at this company. F1 Shake Mix is rich in vitamins and substances needed by the body to help regenerate damaged body cells. In addition, breakfast with these products can manage a weight that affects long-term health (Herbalife.com).

Herbalife distributes its products using a network model known as Multi-Level Marketing (MLM). The sale of Herbalife products is carried out by Herbalife Members as Independent Distributors with a direct selling system and is a member of the Indonesian Direct Sales Association (ADSS). As a member of ADSS, it is possible Herbalife experienced a decrease in sales in Indonesia during the Covid19 pandemic. This is based on a survey conducted by Bank Indonesia that there was a decrease in sales in retail business in March 2020. In addition, many people are experiencing a reduction in income, resulting in a reduction in purchasing power (Yuniati \& Amini, 2020).

To maintain the ability of consumers to pay at a premium price (Willingness to Pay a Price Premium) need to be done various steps. Willingness to pay (WTP), according to Cha et al. (2009), is the willingness to give maximum payment to a product because it influences the environment. Biswas (2016) explained that willingness to pay (WTP) is the willingness of consumers to provide high prices to get a service or goods from a particular brand. While the premium price, according to Aguilar and Vlosky (2007), is the nominal amount issued by consumers to ensure the acquisition of needs and wants. Various steps can be done to maintain Willingness to Pay a Price Premium, one of which is to strengthen Brand Loyalty (Lumba (2019), Chairy (2019).

High brand loyalty can cause a person to be willing to make payments at a higher price (Kwan so Shin et al., 2019). Consumer loyalty to a brand can be pursued by improving the Brand Experience. This is in accordance with Bambang et al. (2017) research, which states that brand experience has a positive and significant effect on brand loyalty. Similarly, Kusuma research (2014) explains that the better the Brand Experience can increase brand loyalty. But the results differ from Pranadata et al.'s (2017) research that states brand experience does not significantly influence brand loyalty, while the study of Putra and Keni (2020) found that brand experience partially has a negative and significant relationship to brand loyalty.

With the inconsistency of the results of previous research on the influence of Brand Experience on Brand Loyalty, researchers get a gap to research by adding Customer Satisfaction variables to mediate the relationship between the two variables. In addition, there has been no previous research that uses the four variables, namely Brand Experience, Customer Satisfaction, Brand Loyalty, and Willingness to Pay a Price Premium, simultaneously in one research model. Likewise, there is still rare research on Willingness to Pay a Price Premium on its main nutritional products during the Covid-19 Pandemic.

\section{Literature Review}

\section{Consumer Behavior}

Sumarwan (2004) explained that consumer behavior is a series of physical and psychological activities carried out by consumers to obtain, utilize and consume a good or service until the evaluation stage, after making various considerations that produce decisions that drive the action. Kotler and Keller (2009) define consumer behavior as a study of how consumers meet their needs and desires, starting from making choices, transacting, and consuming goods or services or ideas and experiences to benefit individuals, groups, or organizations. From consuming an item will gain experience over a product, and 
if a positive experience tends to be followed by a desire to get a similar experience by consuming products from the same brand, so that from interaction with a product for a long time will form an emotional bond in the form of comfort over the brand in question and have the willingness to make payments above the market price compared to other brands (Kwan so Shin et al., 2019).

\section{Brand Experience and Brand Loyalty}

According to Brakus et al. (2009), Brand Experience is subjectivity as an internal consumer response to sensation, feeling, and cognition arising from interaction with a brand and the emergence of behavior from those interactions. In comparison, Khan and Fatma (2017) explained that brand experience is a perception that appears and forms in customers' minds during interaction with brands, from finding information, buying, and receiving to consuming products from a brand. The pleasant experience of consuming a product can encourage a person to recommend it to others, and the desire is born not to switch to consuming alternative brands (Sahin, Zehir \& Kitapci, 2011).

Kusuma (2014) examined the influence of brand experience with a qualitative approach through case studies on Harley Davidson consumers in Surabaya. This research explains that Brand Experience affects Brand Loyalty. But Pranadata, Rahayu, and Hussein's (2017) research show that brand experience has no direct effect on brand loyalty. So is Putra and Keni's research (2020) explains that Brand Experience partially has a negative and significant relationship with Brand Loyalty. While Bambang, Lubis, and Darsono (2017) examined the Brand experience of Gayo Aceh Coffee consumers, this study proved that Brand Experience has a positive and significant influence on brand loyalty. It can be said that a positive brand experience can increase brand loyalty, or in other words, brand loyalty is influenced by brand experience. From the results of existing research can be taken the following hypotheses:

H1: Brand Loyalty is positively and significantly influenced by the Brand Experience.

\section{Customer Satisfaction and Brand Loyalty}

Kotler and Keller (2009) describe satisfaction as a perception of likes or dislikes, reflecting the results of a comparison of consumer expectations with the results received from the performance of a product. While customer satisfaction) is the gap between consumers' expectations for the work performance of a product with the output obtained (Tjiptono, 2004)? The satisfaction that arises after consuming a product from a particular brand can cause a person to still choose products from similar brands to be consumed in the future and cause loyalty to a brand (Ahmed, Rizwan, Ahmad \&Hag, 2014).

The research of Ahmed, Rizwan, Ahmad, and Haq (2014) investigated the influence of customer satisfaction on brand loyalty at the "Hewlett Packard Product" company in Bahawalpur, Pakistan. The research explains that customer satisfaction has a positive and significant relationship with brand loyalty. Likewise, Susanti's research (2019) in the Indonesian Chemical Industry market with the study results showed that customer satisfaction has a significant effect on brand loyalty. From the results of existing research, it can be hypothesized that:

H2: Brand Loyalty is positively and significantly affected by Customer Satisfaction.

\section{Brand Experience and Brand Loyalty through Customer Satisfaction}

A positive and impressive brand experience during the consumption of a product from a particular brand can increase customer satisfaction, where customer satisfaction results from accumulated customer experience in consumer products from a brand (Iglesias et al., 2019). Brand loyalty can be increased to increase customer satisfaction felt by consumers, which is obtained after consuming a product from a particular brand where it is characterized by a repurchase of products from the same brand (Ahmed et al., 2014). 
Hussein's research (2018) tested brand experience relationships on brand loyalty through customer satisfaction. The research was conducted by survey method at five restaurants in Malang City, East Java. This study shows that brand experience affects brand loyalty, either directly or indirectly through customer satisfaction. This indicates that customer satisfaction can be a good mediation variable between brand experience and brand loyalty. From the results of existing research, it can be drawn the hypothesis that:

H3: Brand loyalty is positively and significantly affected by brand experience through customer satisfaction.

\section{Brand Loyalty and Willingness to Pay a Price Premium}

According to Sumarwan (2017), brand loyalty is a customer's response to a positive brand followed by a strong willingness to keep making purchases on an ongoing basis. According to Oliver 1999 in Kaur et al. (2020), Brand loyalty is a strong willingness to carry out regular repurchases and provide support or protection to a product from a particular brand. However, many influences from marketers of other brands offer advantages that allow displacement. Brand loyalty is customer loyalty to a brand, which chooses to continue using the brand in question because of satisfaction and comfort over the brand in question and willingness to make payments above the market price compared to other brands (Kwan so Shin et al., 2019).

Chairy's research (2018) tested the relationship of brand loyalty to a willingness to pay a premium price in users of Rolex brand watches. Data was collected through questionnaires distributed to 150 respondents selected according to the purposive sampling technique, and then data was processed with SPSS 20.0. This study shows that brand loyalty has a positive and significant influence on willingness to pay a premium price. Furthermore, the Lumba research (2019) looked at the impact of Brand Loyalty on Willingness to Pay a Price Premium related to iPhone purchases in Surabaya had a significant effect. So it is known that the higher the level of loyalty of iPhone consumers, the more willing consumers are to pay higher. From the results of existing research, the following hypotheses can be determined:

H4: Brand loyalty has a positive and significant effect on willingness to pay a premium price.

\section{Method}

The type of research used in this study is causal research. The sample in this study was as many as 100 respondents with purposive sampling techniques. The data collection tool used in this study is to use questionnaires, where questionnaires are distributed using Google form and submitted directly to respondents. All items are evaluated using a five-point Likert scale, ranging from $1=$ strongly disagree to $5=$ strongly agree. To see variable categories, use category selections 1 through 5 .

The validity and reliability test is conducted using IBM SPSS version 23 before examining the model in full. The instrument is declared valid if the loading factor value is more significant than 0.5 (Sekaran, 2006). In comparison, the study instrument is called reliable if it has a value of Alpha Cronbach's > 0.7 (Wijaya, 2012). The data analysis in this study uses the Partial Least Square (PLS) method. PLS can be used on any data scale (nominal, ordinal, interval, ratio) and more flexible assumption requirements. PLS is also used to measure the relationship of each indicator to its construct. In addition, in PLS, bootstrapping tests can be done against structural models that are outer and inner models (Ghozali, 2013).

In this study, we looked at the influence of brand loyalty on the willingness to pay a premium price of Herbalife product nutrition consumers, where brand loyalty is influenced by brand experience as an independent variable (endogenous variable). Based on previous research, there are still inconsistencies 
in the influence of brand experience on brand loyalty, so there needs to be a variety that mediates the relationship between the two variables by adding customer satisfaction as a mediation variable. Here's the conceptual framework for this research:

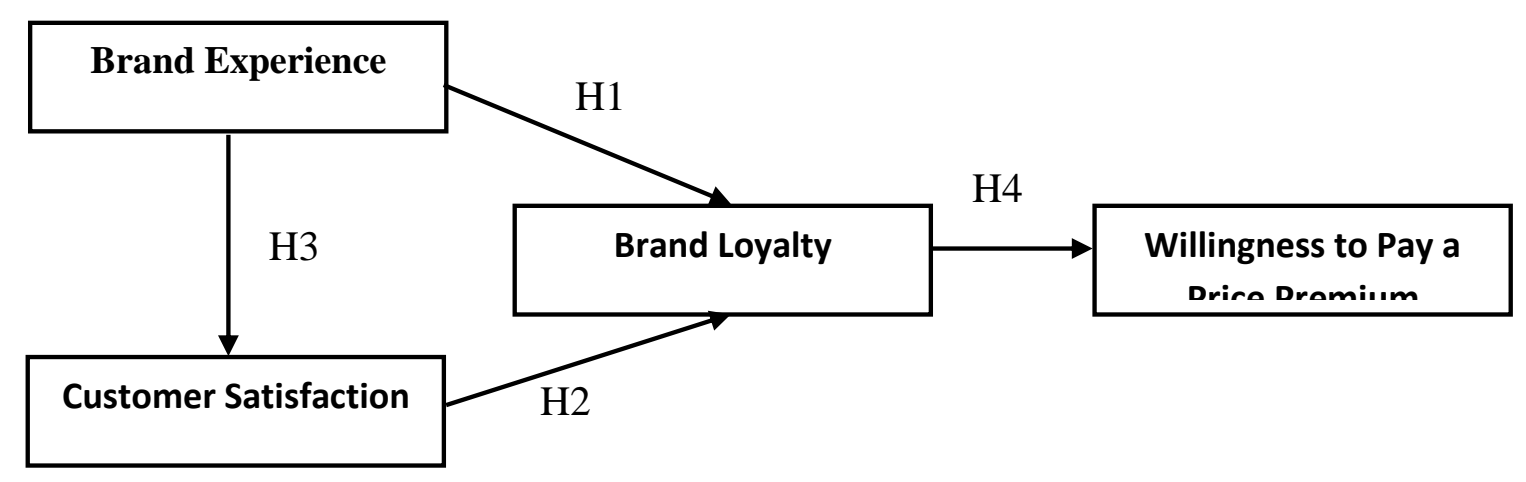

Gambar 1. Kerangka Konseptual

\section{Result and Discussion}

\section{Result}

This respondent's description analysis aims to obtain characteristic data on 100 research samples, including gender, age, education, occupation, and length of consumption of Herbalife nutrition.

\begin{tabular}{llll}
\hline Variable & Description & Sum & \% \\
\hline Gender & Man & 27 & 27 \\
Age of respondents & Woman & 63 & 63 \\
& 17-27 year & 13 & 13 \\
& 28-38 year & 48 & 48 \\
39-49 year & 31 & 31 \\
Work & 50 Years and above & 8 & 8 \\
& Student & 10 & 10 \\
& Self-employed & 45 & 45 \\
CIVILS /BUMN Employees & 12 & 12 \\
Education & Private Employees/Honorees & 25 & 25 \\
& TNI/POLRI & 3 & 3 \\
& Others (Housewife) & 5 & 5 \\
& Junior High School & 9 & 9 \\
& Senior High School & 38 & 38 \\
& Diploma & 13 & 13 \\
Long consumed & Bachelor & 32 & 32 \\
& Magister & 3 & 3 \\
& Others (Elementary School) & 5 & 5 \\
& Less than three months & 15 & 15 \\
& 4-12 months & 47 & 47 \\
& 13-24 months & 13 & 13 \\
& > 24 months & 35 & 35 \\
\hline
\end{tabular}


Analyze the data in this study using PLS (Partial Least Square) through PLS version 3.0. PLS can be used for theory confirmation (Ghozali, 2014). Pls models contain two elements of measurement, namely structural models or called inner model models and measurement models or outer models. The inner model describes the relationships between latent variables in a model. The outer model draws latent variable relationships with each indicator (Hair et al., 2013).

\section{Measurement Model (Outer Model)}

The outer model is used to test the validity of the construct and the reliabilities of the instrument. According to Abdillah, Willy, and Jogiyanto (2015) outer model or measurement model describes the relationship between groups of indicators with latent variables. Based on AVE and communality values, all of the study's variable indicators are declared to qualify for convergent validity. Where AVE and communality are all variables above the cut-off value of 0.5 . Items are declared convergent validity if the AVE and communality values $>0.5$ and outer loading $>0.6$. (Hair et al., 2013).

Tabel 2. Model Pengukuran Indikator

\begin{tabular}{|c|c|c|c|c|c|}
\hline Kode & Variable & $\begin{array}{l}\text { Outer } \\
\text { Loading }\end{array}$ & $\begin{array}{l}\text { Cronbach's } \\
\text { Alpha }\end{array}$ & $\begin{array}{l}\text { Composite } \\
\text { Reliability }\end{array}$ & AVE \\
\hline & BRAND EXPERIENCE & & 0.955 & 0.963 & 0.763 \\
\hline BE1 & I feel excited to consume Herbalife nutrients & 0.763 & & & \\
\hline BE2 & I feel energized by Herbalife nutrition & 0.894 & & & \\
\hline BE3 & I'm interested in Herbalife nutrition. & 0.881 & & & \\
\hline BE4 & I'm comfortable drinking Herbalife nutrients & 0.905 & & & \\
\hline BE5 & I remember Herbalife products & 0,891 & & & \\
\hline BE6 & I actively eat Herbalife breakfast products & 0,882 & & & \\
\hline BE7 & I changed my diet after I consumed Herbalife. & 0,888 & & & \\
\hline \multirow[t]{2}{*}{ BE8 } & I replaced my breakfast with Herbalife. & 0,875 & & & \\
\hline & CUSTOMER SATISFACTION & & 0,954 & 0,961 & 0,721 \\
\hline CS1 & $\begin{array}{l}\text { I am satisfied to be able to consume Herbalife } \\
\text { nutrients }\end{array}$ & 0,880 & & & \\
\hline CS2 & I'm glad I bought Herbalife products. & 0,859 & & & \\
\hline CS3 & $\begin{array}{l}\text { I feel fulfilled nutritional needs with Herbalife } \\
\text { breakfast }\end{array}$ & 0,822 & & & \\
\hline CS4 & I love to consume Herbalife. & 0,871 & & & \\
\hline CS5 & I'm glad I can drink Herbalife. & 0,880 & & & \\
\hline CS6 & I'm glad I had Herbalife breakfast. & 0,904 & & & \\
\hline CS7 & I'm happy to have breakfast with Herbalife. & 0,916 & & & \\
\hline \multirow[t]{2}{*}{ CS8 } & I feel healthier breakfast with Herbalife & 0,820 & & & \\
\hline & BRAND LOYALTY & & 0.921 & 0.939 & 0,756 \\
\hline BL1 & $\begin{array}{l}\text { Herbalife became my No. } 1 \text { choice for nutritional } \\
\text { products }\end{array}$ & 0,740 & & & \\
\hline BL2 & $\begin{array}{l}\text { I don't buy any nutritional products other than } \\
\text { Herbalife. }\end{array}$ & 0,888 & & & \\
\hline BL3 & I still consume Herbalife. & 0,922 & & & \\
\hline BL4 & I still want breakfast with Herbalife. & 0,886 & & & \\
\hline BL5 & I said good things about Herbalife. & 0.845 & & & \\
\hline \multirow[t]{2}{*}{ BL6 } & $\begin{array}{l}\text { If a friend asks for advice on malnutrition, I } \\
\text { recommend Herbalife. }\end{array}$ & 0,800 & & & \\
\hline & Willingness To Pay a Price Premium & & 0.958 & 0.966 & 0,827 \\
\hline WTPP1 & $\begin{array}{l}\text { I want to pay Herbalife at a premium / expensive } \\
\text { price }\end{array}$ & 0,883 & & & \\
\hline WTPP2 & I still buy Herbalife products even though they are & 0,899 & & & \\
\hline
\end{tabular}




\begin{tabular}{|c|c|c|c|c|c|}
\hline Kode & Variable & $\begin{array}{l}\text { Outer } \\
\text { Loading }\end{array}$ & $\begin{array}{l}\text { Cronbach's } \\
\text { Alpha }\end{array}$ & $\begin{array}{l}\text { Composite } \\
\text { Reliability }\end{array}$ & AVE \\
\hline & expensive. & & & & \\
\hline WTPP3 & I don't buy other products even if they're cheaper. & 0,908 & & & \\
\hline WTPP4 & $\begin{array}{l}\text { I chose Herbalife, although many discounts on other } \\
\text { products }\end{array}$ & 0,900 & & & \\
\hline WTPP5 & $\begin{array}{l}\text { I bought Herbalife even though it's more expensive } \\
\text { than other products }\end{array}$ & 0,923 & & & \\
\hline WTPP6 & $\begin{array}{l}\text { I still choose Herbalife at a higher price than other } \\
\text { brands. }\end{array}$ & 0,942 & & & \\
\hline
\end{tabular}

\section{Structural Model (Inner Model)}

After the evaluation of measurements (outer model) is fulfilled, then it is necessary to evaluate the structural model (inner model). The following are the results of the evaluation of structural models in this study.

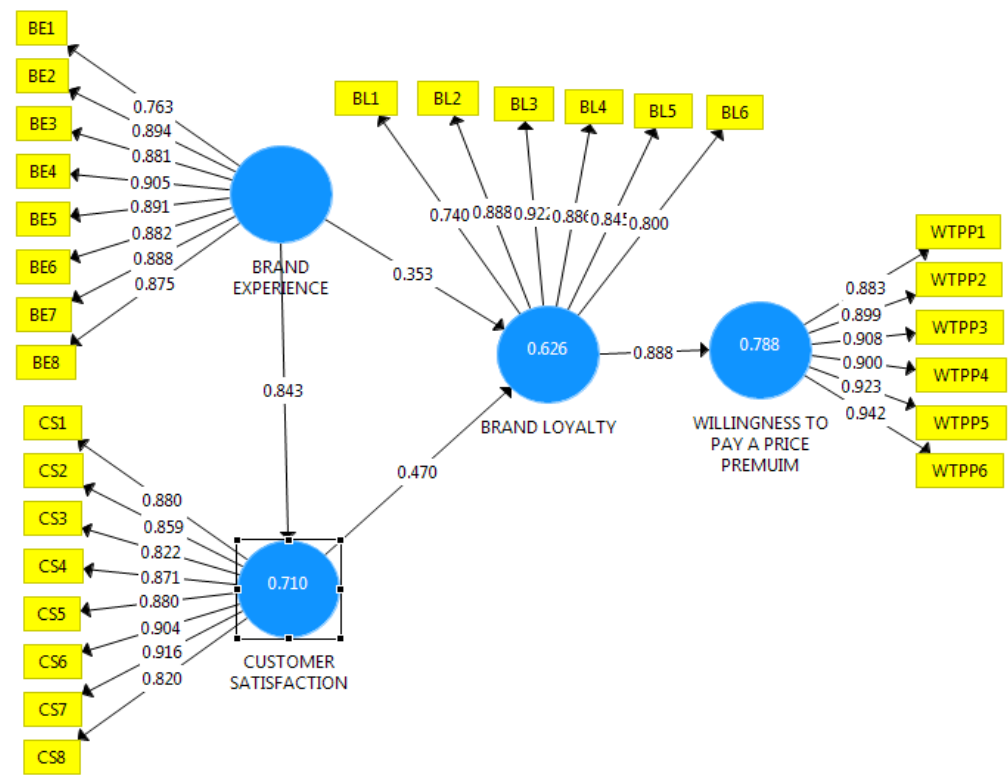

Figure 2. Structural Model (Inner Model)

Obtained path coefficient or weight of the influence of Brand Experience variable (BE) on Brand Loyalty (BL) is 0.353 , the weight of the impact of variable Customer Satisfaction (CS) on Brand Loyalty (BL) of 0.470, and the weight of the influence of variable Brand Loyalty on Willingness to Pay APrice premium is 0.888 . The PLS Structural Model can be assessed by looking at the R-Square value of each endogenous variable as the predictive strength of the structural model. Based on the above figure obtained the R-square value on the Customer Satisfaction variable of 0.710 , this value indicates that the Brand Experience variable describes the Customer Satisfaction variable by $71 \%$. In comparison, $29 \%$ is explained by other variables not included in the study. The R-square value on the Brand Loyalty variable is 0.626. This value indicates that the Brand Loyalty variable is described by the Brand Experience variable by $62.6 \%$, while $37.4 \%$ is explained by other variables not included in the study. The R-square value on the Willingness to Pay a Price Premium variable is 0.788 . This value indicates that the Willingness To Pay a Price Premium variable is described by the Brand Loyalty variable at $78.8 \%$. In comparison, $21.2 \%$ is explained by other variables not included in the study. Overall the structural models 
in the study were in the Moderate category, as endogenous variables had R-square values greater than 0.33 .

\section{Hypothesis Test (Bootstrapping Resampling)}

The hypothesis test looks at the path coefficient values that show the parameter coefficient and the t-statistical value. The significance of the estimated parameter provides information regarding the relationship between the research variables then compares the value of the t-statistic with the t-table of significance at $5 \%$ (the value of t-count $>$ t-table 1.984). The results of the hypothesis test can be seen in table 3 and 4 as follows:

\begin{tabular}{llllrll}
\multicolumn{7}{c}{ Table 3. Direct Influence Hypothesis Test } \\
\hline Hypothesis & $\begin{array}{l}\text { Original } \\
\text { Sample Estimate }\end{array}$ & $\begin{array}{l}\text { Mean Of } \\
\text { jubsamples }\end{array}$ & $\begin{array}{l}\text { Standard } \\
\text { Deviation }\end{array}$ & & & \\
\hline BE $\rightarrow$ BL & 0,353 & 0,358 & 0,126 & 2.997 & 0,003 & Accepted \\
CS $\rightarrow$ BL & 0,470 & 0,469 & 0,122 & 4.123 & 0,000 & Accepted \\
BL $\rightarrow$ WTPP & 0,888 & 0,887 & 0,028 & 29.638 & 0,000 & Accepted \\
\hline
\end{tabular}

Tabel 4. Uji Hipotesis Pengaruh Tidak Langsung

\begin{tabular}{ccccccc}
\hline Hypothesis & $\begin{array}{c}\text { Original } \\
\text { Sample } \\
\text { Estimate }\end{array}$ & $\begin{array}{c}\text { Mean Of Sub Standard } \\
\text { samples } \\
\text { Deviation }\end{array}$ & T-Statistic P-Values & Result \\
\hline $\mathrm{BE} \rightarrow \mathrm{CS} \rightarrow \mathrm{BL}$ & 0,397 & 0,394 & 0,100 & 3,979 & 0,000 & Accepted \\
\hline
\end{tabular}

\section{a) The Influence of Brand Experience on Brand Loyalty (BE $\rightarrow$ BL)}

The hypothesis test results are known to be the value of the variable parameter coefficient Brand Experience 0.353 and the t-statistical value of 2,997 more excellent than the t-table (significant at 0.05). Then $\mathrm{H} 1$ is accepted so that it can be concluded that brand experience has a significant positive effect on brand loyalty.

\section{b) The Effect of Customer Satisfaction on Brand Loyalty $(\mathrm{CS} \rightarrow \mathrm{BL})$}

The hypothesis test results are known to be the coefficient value of the variable parameter Customer Satisfaction 0.470 and the t-statistical value of 4.123 more excellent than the t-table (significant at 0.05). Then $\mathrm{H} 2$ is accepted so that it can be concluded that Customer Satisfaction has a significant positive effect on Brand Loyalty.

\section{c) The Influence of Brand Experience affects Brand Loyalty through Customer Satisfaction $(\mathrm{BE} \rightarrow \mathrm{CS} \rightarrow \mathrm{BL})$}

The results of the hypothesis tests are known to be the coefficient value of variable parameters $\mathrm{BE} \rightarrow \mathrm{CS} \rightarrow \mathrm{BL} 0.397$ and the t-statistical value is 3.979 greater than the t-table (significant at 0.05). Then H3 is accepted so that it can be concluded that brand experience has a significant positive effect on brand loyalty through customer satisfaction.

\section{d) Influence of Brand Loyalty on Willingness to Pay a Premium Price (BL $\rightarrow$ WTPP)}

The hypothesis test results are known to be the coefficient value of the Variable Parameter Brand Loyalty 0.888 and the t-statistical value of 29.638 greater than the t-table (significant at 0.05 ). Then $\mathrm{H} 4$ is accepted so that it can be concluded that Brand Loyalty has a significant positive effect on willingness to pay a premium price.

\section{Discussion}

The results of this study revealed that The Brand Experience positively and significantly influences brand Loyalty. The discovery can be interpreted that the more positive the brand experience 
(Brand Experience) of Herbalife consumers, the higher the brand loyalty (Brand Loyalty) of consumers concerned about Herbalife nutrition. Positive experiences and optimal results in consuming products from the brand in question can give birth to brand loyalty (Brand Loyalty).

The existence of high Customer Satisfaction in Herbalife consumers is due to the increase in Brand Loyalty of Herbalife consumers. This can be seen from respondent questionnaire answers related to statements on Brand Loyalty items that show a high average value. This study resulted in the finding that Brand Loyalty is positively affected by Customer Satisfaction. This can be interpreted that the higher the customer satisfaction in consuming a product with a particular brand, the higher the consumer's brand loyalty to a product with the brand in question. High customer satisfaction will be causing customers to continue to get similar satisfaction in consuming the same brand.

A positive Brand Experience obtained by consumers after consuming a product from a particular brand, accompanied by high customer satisfaction with the product of the brand in question, can further increase brand loyalty (Brand Loyalty) of the consumer concerned. The findings in this study support the results of previous research conducted by Yuliansyah and Handoko (2019), which explained that Customer Satisfaction could be a good mediation variable independent variable relationship to Brand Loyalty in the study. Furthermore, the results of this study also strengthen the results of Irawati's research (2020), which states that Customer Satisfaction can mediate the relationship between Brand Experience and Brand Loyalty in Boncabe consumers in Jakarta.

This research proves that Brand Loyalty has a significant positive influence on Willingness to Pay a Price Premium. This can be explained that the higher the consumer's Brand Loyalty to a brand, the stronger the willingness to pay a price premium even during the Covid-19 pandemic. The existence of high Brand Loyalty in this study, influenced by the presence of a positive Brand Experience and high Customer Satisfaction from Herbalife consumers, so it affects Willingness to Pay a Price Premium. To maintain and increase willingness to pay (Willingness to Pay a Price Premium) can be done by increasing the consumer's brand loyalty to a product of the brand in question.

\section{Conclusion}

This study shows that: (1) Brand Loyalty is positively and significantly affected by the Brand Experience. This can be interpreted that the more positive the Brand Experience obtained by customers from consuming a product from a particular brand, the higher the Brand Loyalty from consumers to the intended brand; (2) Brand Loyalty is positively and significantly affected by Customer Satisfaction. It can be explained that the higher customer satisfaction felt by consumers towards the product of a brand can increase consumer brand loyalty in a product with the brand in question; the Brand Experience positively and significantly influences (3) Brand Loyalty through Customer Satisfaction. This can be interpreted that the increasingly positive Brand Experience of Herbalife consumers accompanied by high customer satisfaction further strengthens the Brand Loyalty of consumers to Herbalife product nutrition; (4) Brand Loyalty affects Willingness to Pay a Price Premium positively and significantly. This can be interpreted that the higher the Brand Loyalty of a Herbalife consumer, the higher willingness to pay a premium price to the nutrition of Herbalife products.

\section{References}

Abdillah, W. dan J. (2015), Strktural Partial Least Square (PLS) Altrnatif Bisnis Equation Modeling (SEM) Dalam Penelitian ( $1^{\text {st }}$ ed.). ANDI

Aguilar, F. X., \& Vlosky, R. P. (2007). Consumer willingness to pay price premiums for environmentally 
certified wood products in the U.S. Forest Policy and Economics, 9(8), 1100-1112. https://doi.org/10.1016/j.forpol.2006.12.001

Ahmed, Z., Rizwan, M., Ahmad, M., \& Haq, M. (2014). Effect of brand trust and customer satisfaction on brand loyalty in Bahawalpur. Journal of Sociological Research, 5(1), 306-326. https://doi.org/10.5296/jsr.v5i1.6568

Bambang, Lubis, A. R., \& Darsono, N. (2017). Pengaruh Brand Image, Brand Personality, Brand Experience terhadap Brand Love Dampaknya pada Brand Loyalty Gayo Aceh Coffee PT. Oro Kopi Gayo Kabupaten Aceh Tengah. Jurnal Perspektif Manajemen Dan Perbankan, 8(3), 158-184.

Başer, İ. U., Cintamür, İ. G., \& Arslan, F. M. (2016). Examining the Effect of Brand Experience on Consumer Satisfaction, Brand Trust and Brand Loyalty. İktisadi ve İdari Bilimler Dergisi, 37(2), 101. https://doi.org/10.14780/iibd.51125

Biswas, A. (2016). A Study of Consumers' Willingness to Pay for Green Products. Journal of Advanced Management Science, 4(3), 211-215. https://doi.org/10.12720/joams.4.3.211-215

Brakus, J. J., Schmitt, B. H., \& Zarantonello, L. (2009). Brand Experience: What Is It? How Is It Measured? Does It Affect Loyalty? Journal of Marketing, 73(3), 52-68. https://doi.org/10.1509/jmkg.73.3.52

Cha, J., Chun, J., \& Youn, Y. (2009). Consumer Willingness to Pay Price Premium for Certified Wood Products in South Korea. Journal of Korean Forest Society, 211(2), 203-211.

Chairy, T. P. D. (2019). Pengaruh Brand Loyalty, Brand Love, Brand Commitment Terhadap Willingness To Pay A Premium Price. Jurnal Manajemen Bisnis Dan Kewirausahaan, 2(1), 89-97. https://doi.org/10.24912/jmbk.v2i1.4813

Dwivedi, A., Nayeem, T., \& Murshed, F. (2018). Brand experience and consumers' willingness-to-pay (WTP) a price premium: Mediating role of brand credibility and perceived uniqueness. Journal of Retailing and Consumer Services, 44(June), 100-107.

Ghozali, I. (2013), Model Persamaan Struktural Konsep Dan Aplikasi Dengan Program Amos 21.0, Semarang: Badan Penerbit Universitas Diponegoro

Hair, J. F., Ringle, C. M., \& Sarstedt, M. (2013). Partial Least Squares Struktural Equation Modeling: Rigorous Applications, Better Results and Higher Acceptance. In Long range Planning. https://doi.org/10.1016/j.lrp.2013.01.001

Hussein, A. S. (2018). Effects of brand experience on brand loyalty in Indonesian casual dining restaurant: Roles of customer satisfaction and brand of origin. Tourism and Hospitality Management, 24(1), 119-132. https://doi.org/10.20867/thm.24.1.4

Iglesias, O., Markovic, S., \& Rialp, J. (2019). How does sensory brand experience influence brand equity? Considering the roles of customer satisfaction, customer affective commitment, and employee empathy. Journal of Business Research, 96(May 2018), 343-354. https://doi.org/10.1016/j.jbusres.2018.05.043

Kaur, H., Paruthi, M., Islam, J. U., \& Hollebeek, L. D. (2020). The role of brand community identification and reward on consumer brand engagement and brand loyalty in virtual brand communities. Telematics and Informatics, 46, 101321. https://doi.org/10.1016/j.tele.2019.101321 
Khan, I., \& Fatma, M. (2017). Antecedents and outcomes of brand experience: An empirical study. Journal of Brand Management, 24(5), 439-452. https://doi.org/10.1057/s41262-017-0040-x

Kotler, P., \& Keller, K. L. (2009), Manajemen Pemasaran Edisi Ketiga Belas, Jakarta: Erlangga.

Kusuma, Y. S. (2014). Pengaruh Brand Experience Terhadap Brand Loyalty Melalui Brand Satisfaction Dan Brand Trust Harley Davidson Di Surabaya. Jurnal Manajemen Pemasaran Petra, 2(1), 1-11.

Kwan Soo Shin, S., Amenuvor, F. E., Basilisco, R., \& Owusu-Antwi, K. (2019). Brand Trust and Brand Loyalty: A Moderation and Mediation Perspective. Current Journal of Applied Science and Technology, November, 1-17. https://doi.org/10.9734/cjast/2019/v38i430376

Lidia, K., Levina, E., Setianingrum, S., Folamauk, C., Riwu, M., Lidesna, A., \& Amat, S. (2020). Peningkatan Kesehatan dengan Suplemen dan Gizi Seimbang di Era Pandemi Covid-19. Jurnal Lembaga Pengabdian Kepada Masyarakat Undana, 14(2), 6368. http://ejurnal.undana.ac.id/jlppm/article/view/3445

Lumba, M. G. (2019). Peran Brand Love Terhadap Brand Loyalty Dan Willingness To Pay Premium Price Pada Pembeli Iphone Di Surabaya. Agora, 7(1), 287271.

Masrul, M. (2018). Epidemi obesitas dan dampaknya terhadap status kesehatan masyarakat serta sosial $\begin{array}{lllll}\text { ekonomi } & \text { bangsa. }\end{array}$ https://doi.org/10.25077/mka.v41.i3.p152-162.2018

Noviasty, R., \& Susanti, R. (2020). Perubahan Kebiasaan Makan Mahasiswa Peminatan Gizi Selama Masa Pandemi Covid 19. Jurnal Kesehatan Masyarakat Mulawarman (JKMM), 2(2), 90. https://doi.org/10.30872/jkmm.v2i2.5079

Pranadata, I. G. P., Rahayu, M., \& Hussein, A. S. (2017). ANALISIS PENGARUH BRAND EXPERIENCE TERHADAP BRAND PERCEIVED VALUE, BRAND SATISFACTION, DAN BRAND LOYALTY ( Studi Kasus Pada Industri One Stop Carcare Service di Kota Malang) I Gede Putu Pranadata, Mintarti Rahayu, Ananda Sabil Hussein. Jurnal Bisnis Dan Manajemen, 4(2), $217-$ 228.

Priambodo, L. H., \& Najib, M. (2016). Analisis Kesediaan Membayar (Willingness to Pay) Sayuran Organik dan Faktor-Faktor yang Mempengaruhinya. Jurnal Manajemen Dan Organisasi, 5(1), 1. https://doi.org/10.29244/jmo.v5i1.12125

Putra, T. W., \& Keni, K. (2020). Brand Experience, Perceived Value, Brand Trust Untuk Memprediksi Brand Loyalty: Brand Love Sebagai Variabel Mediasi. Jurnal Muara Ilmu Ekonomi Dan Bisnis, 4(1), 184. https://doi.org/10.24912/jmieb.v4i1.7759

Şahin, A., Zehir, C., \& Kitapçi, H. (2011). The effects of brand experiences, trust and satisfaction on building brand loyalty; an empirical research on global brands. Procedia - Social and Behavioral Sciences, 24, 1288-1301. https://doi.org/10.1016/j.sbspro.2011.09.143

Sumarwan, U. (2004), Perilaku Konsumen Teori Dan Penerapannya Dalam Pemasaran, Jakarta: Ghalia Indonesia.

Susanti, V. (2019). Pengaruh Perceived Brand Quality, Perceived Value Dan Switching Cost Terhadap Customer Satisfaction Dan Brand Loyalty: Studi Pasar Industri Kimia Di Indonesia. Mix: Jurnal Ilmiah Manajemen, 9(2), 282. https://doi.org/10.22441/mix.2019.v9i2.003

Tjiptono,F. (2008), Strategi Pemasaran, Edisi ketiga, Jakarta: ANDI 
Wijaya, T. (2012) Cepat Menguasai SPSS 20, Jakarta: Cahaya Atma Pustaka

Wuryandani, D. (2020). Dampak Pandemi Covid-19 terhadap Pertumbuhan ekonomi Indonesia 2020 dan Solusinya. Pusat Penelitian Badan Keahlian DPR RI, Bidang Ekonomi Dan Kebijakan Publik.

Zhang, Y., Xiao, C., \& Zhou, G. (2020). Willingness to pay a price premium for energy-saving appliances: Role of perceived value and energy efficiency labeling. Journal of Cleaner Production, 242, 118555. https://doi.org/10.1016/j.jclepro.2019.118555

Yuniati, M. Amini, R. (2020). Analisis Dampak Covid-19 Terhadap Daya Beli Masyarakat NTB. Jurnal Penelitian Manajemen, Vol.2 No.2.

Zeithaml, V.A., Bitner, M.J., \& Gremler, D.D. (2006). Servise Marketing: Intergrating Customer fokus across the firm ( $4^{\text {th }}$ ed., pp. 117). Singapore: McGraw-Hill

\section{Copyrights}

Copyright for this article is retained by the author(s), with first publication rights granted to the journal.

This is an open-access article distributed under the terms and conditions of the Creative Commons Attribution license (http://creativecommons.org/licenses/by/4.0/). 